\title{
Gypsophila pilosa Hudson, a new species to the Flora of Egypt
}

\author{
S M. El Naggar \\ Botany Department, Faculty of Science \\ Assiut University, Assiut, 71615 Egypt
}

El Naggar, S.M. 2002. Gypsophila pilosa Hudson, a new species to the flora of Egypt. Taeckholmia, 22 (2): 197-200.

Gypsophila pilosa Hudson is recorded for the first time as a weed in recently reclaimed farmland east of Assiut town (Egypt). It was previously known from Libya, Palestine, Turkey and Iran. The occurrence of this species in the Nile land of Egypt fills the gap of its distribution between Palestine (Southwest Asia) and Libya (North Africa) and represents the southernmost limits of its global distribution.

Key words:, Caryophyllaceae, Flora of Egypt, Gypsophila pilosa.

\section{Introduction}

The genus Gypsophila L (Caryophyllaceae) comprises about 120 species of annual or perennial herbs and shrubs, of Mediterranean and Irano-Turanian regions (Davis, 1965; Zohary, 1966; Abdul Ghafoor, 1978).

In Egypt Gypsophila was reported to be represented by only two species viz. G. capillaris (Forssk.) C. Chr. and G. viscosa Murray (Täckholm, 1974). Hosny (1989), followed Danin et al. (1985) in considering G. arabica Barkoudah to be in Sinai. Later Hosny \& El Husseini (1995) added another species viz. G. antari Post \& Beauverd to the flora of Egypt. Boulos (1995 \& 1999) added another species, viz. G. Iinearifolia (Fisch. \& C.A. Mey) Boiss.. Recently, Hosny \& El Hadidi (2000), following Hosny \& El Husseini (op.cit., 1995) reported four Gypsophila species viz. G. capillaris (Forssk.) C. Chr., G. viscosa Murray, G. arabica Barkoudah and G. antari Post \& Beauverd.

In April 2000, a number of specimens were collected by the author from the reclaimed area east of Assiut town (Fig. 1). Among these, there was a specimen which did not match any of the Caryophyllaceous species known hitherto in the flora of Egypt. In February 2001, this specimen was sent to I. C. Hedge (Herbarium of Royal Botanic Garden, Edinburgh, UK) for identification. He kindly identified the specimen as Gypsophila pilosa Hudson.

In the present work Gysophila pilosa is reported as a new element to the flora of Egypt. The present distribution of this taxon as well as a key for the separation between Gypsophila species occurring in Egypt is provided.

Gypsophila pilosa Hudson in Phil. Trans. Roy. Soc. Lond. (B) 56: 252 (1767).

= Hagenia filiformis Moench, Meth. 51 (1794).

= Gypsophila porrigens (Gouan ex L.) Boiss. Fl. Or. 1: 557 (1867).

Annual herb, up to $120 \mathrm{~cm}$. Stem erect, dichotomously branched, thick below, villous or hispid in the middle. Leaves 3.5-11 x 1-3 cm, lanceolate to linear or triangular, acuminate, 3-5 veined, with long glandular hairs, opposite, sessile, entire. Inflorescence dichasial cymes. Bracts linear-lanceolate, hairy. Pedicels filiform, becoming deflexed, glabrous, 3-5-cm. Calyx

Received 3 September, 2002. Revision accepted 28 September, 2002. 
campanulate-tubular, 5-8 mm, glandular-hispid, teeth triangular to subspherical with white margins. Petals 7-13 mm, white to pinkish, linear-oblong, emarginate to shallowly bilobed, clawed. Capsule about as long as calyx or longer, globular, deflexed. Mature seeds numerous, 1.5-2 mm, black with obtuse tubercles, reniform-orbicular (Fig., 2, a, b \& c).

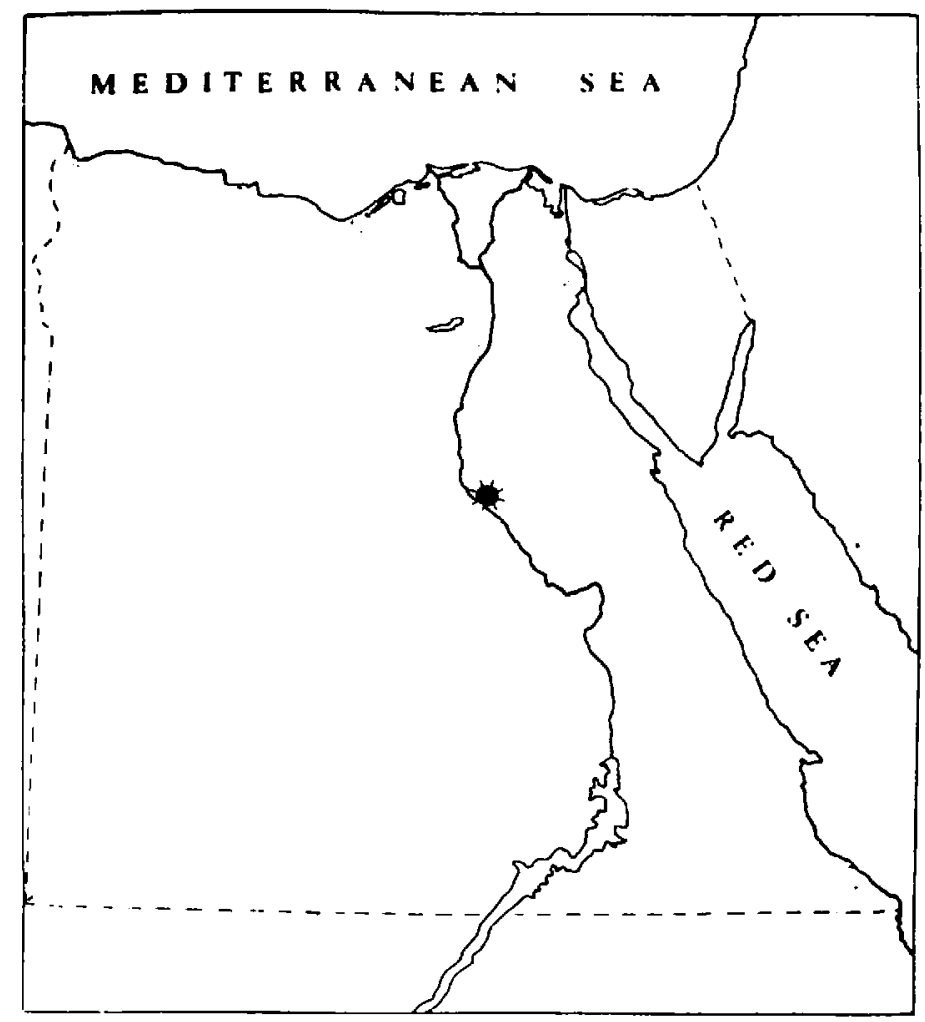

Fig. 1: Shows the present distribution ( ) of Gypsophila pilosa in Egypt

Gypsophila pilosa is a distinct species characterized by its stout hispid or villous long stems; large, linear or triangular and sessile leaves; filiform and glabrous pedicels and relatively large pink and emarginate-bilobed and clawed petals. Barakuda, (1962) classified this species in sect. Hagenia A. Braun. Accordingly, five species of Gypsophila are recognized in Egypt viz.: G. pilosa, G. viscosa, G. capillaris, G. antari and G. arabica. No specimens of Gypsophila linearifolia have been seen by the author, its presence in Egypt is uncertain. Gypsophila pilosa can be separated from the other Gypsophila species occurring in Egypt by the following key. 


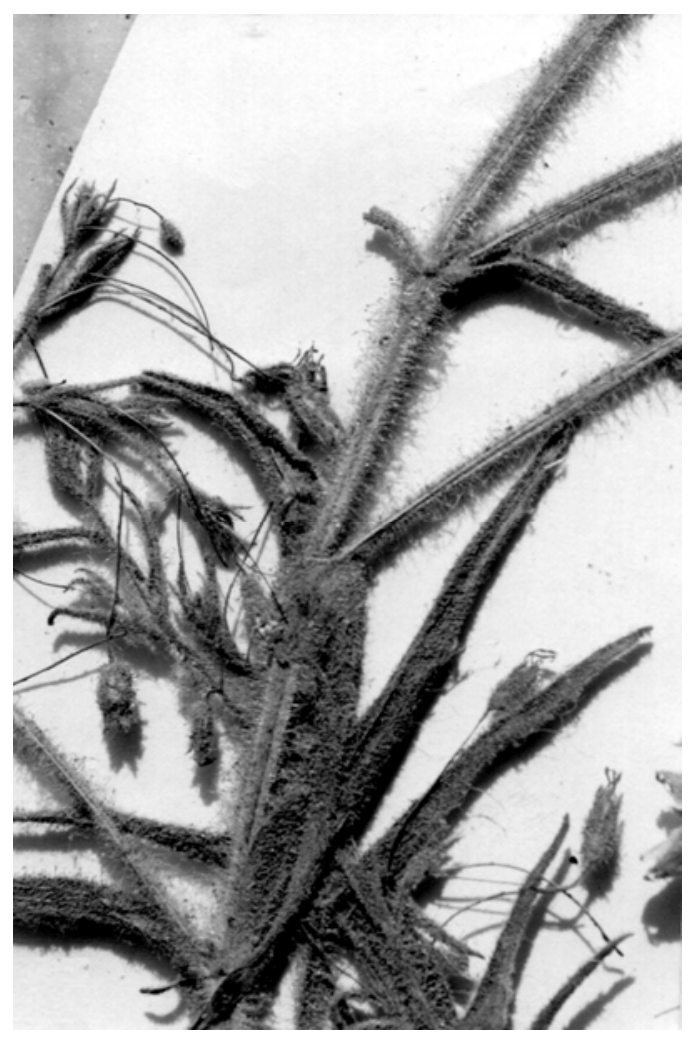

a

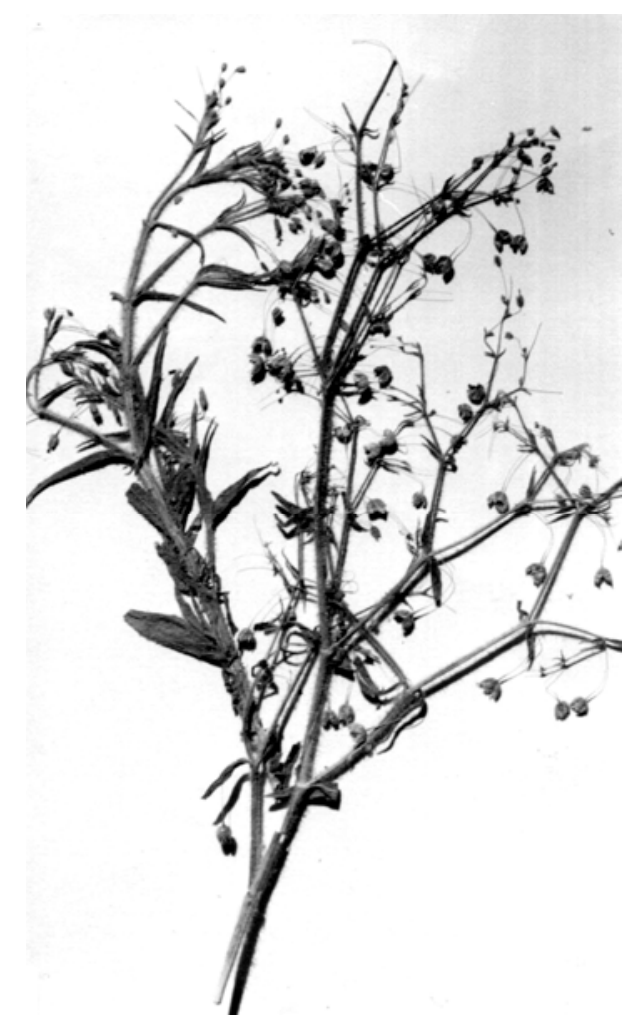

b

Fig. 2: Gypsophila pilosa, a. part of stem with pilose hairs; b. flowering and fruiting plants; c. mature seed as seen by SEM. Eastnorth of Assiut town, reclaimed farmland; Aprile, 2000, El-Naggar, s.n.

1.a. Plants with glandular hairs or sessile glands on at least the upper part ........ 2

b. Plants glabrous throughout ........................................... 3

2.a. Plants villous or hispid in the middle, glabrous above and below; leaves sessile or subsessile lanceolate to triangular, 3.5-11 x 1-3 cm G. pilosa

b. Plants viscous with sessile glands at the internodes; leaves narrowly ovate to ovate oblong, $1.5-6$ x $0.5-1.5 \mathrm{~cm}$.

G. viscosa

3.a. Annual or biennial herbs, basal leaves elliptical or lanceolate...... G. antari

b. Woody perennials, basal leaves narrow. ................................. 4

4.a. Calyx persistent in fruiting; capsule globoid, opens by 4 valves to about $1 / 2$ of its length

G. capillaris

b. Calyx deciduous in fruiting; capsule turbinate, 4 angular, opens by 4 valves till the base of capsule

G. arabica Gypsophila pilosa was found to be growing as weed in the reclaimed farmland east of Assiut town It is probably introduced with new crop plants or/and manures. The occurrence of this taxon in Assiut (Upper Egypt) fills the gap in its distribution between Palestine 
(Southwest Asia) and Libya (North Africa). The record of Gypsophila pilosa in Assiut (Upper Egypt) is considered to be the southernmost limits of its global distribution.

\section{Acknowledgements}

The author would like to thank I. C. Hedge (Herbarium, Royal Botanic Garden, Edinburgh, U.K.) for the identification of this species and Prof. M. N. El Hadidi (Herbarium, Cairo University, CIA) and Prof. A. A. Fayed (Botany Department, Faculty of Science, Assiut University) for their continuous support, fruitful discussion and critical revision of the manuscript.

\section{References}

Abdul Ghafoor, 1978. Flora of Libya, Caryophyllaceae, 59 (eds. Jafri, S. M. H. \& El-Gadi, A.) Al Faateh University, Tripoli.

Barakudah,Y. I. 1962. A revision of Gypsophila, Bolanthus, Ankyropetalum and Phryna. Wentia 9: 1-303.

Boulos, L., 1995. Flora of Egypt, checklist Al Hadara Publ, Cairo. pp 1 -287 1999. Flora of Egypt vol. 1 Azolliaceae-Oxalidaceae Cairo Al Hadara Publishing.

Danin, A., Shmida, A. \& Liston 1985. Contribution to the flora of Sinia. III. Checklist of the species collected and recorded by the Jerusalem team 1967-1982. Willdenowia 15: 255-322.

Davis, P. H. 1965. Flora of Turkey and East Aegean Islands vol. 1 Edinburgh.

El Hadidi, M. N. \& Fayed, A. A. 1994/95. Materials for Excursion Flora of Egypt (EFE) Taeckholmia 15: 15-16.

Hosny, A. I. 1989. Annotated list of the flora of Sinai (Egypt). 2. Angiospermae: SalicaceaeMenispermaceae. Taeckholmia 12: 7-16.

\& El Husseini, N. 1995. Taxonomic studies of Silenoideae (Caryophyllaceae) in Egypt. 3. Tribe Diantheae. Candollea 50: 1-14.

- \& El Hadidi M. N. 2000 Caryophyllaceae in Flora Aegyptiaca, vol. I part 2 (ed. El Hadidi, M.N.), Palm press, Cairo.

Täckholm, V 1974. Students' Flora of Egypt ed 2, Cairo University.

Zohary, M. 1966. Flora Palaestina vol. 1 Israel Acad. Sci. Humanities. Jerusalem. 